\title{
Success Factors for Public-Private Partnership Infrastructure Projects in Vietnam
}

\author{
Phong Thanh Nguyen ${ }^{\mathrm{a}}$, Veerasak Likhitruangsilp ${ }^{\mathrm{b}}$, Masamitsu Onishi ${ }^{\mathrm{c}}$ \\ ${ }^{a}$ Department of Project Management, Ho Chi Minh City Open University, Ho Chi Minh City, 701500, Vietnam \\ E-mail:phong.nt@ou.edu.vn \\ ${ }^{b}$ Division of Construction Engineering and Management, Department of Civil Engineering, Chulalongkorn University, \\ Bangkok, 10330, Thailand \\ E-mail:Veerasak.L@chula.ac.th \\ ${ }^{c}$ Disaster Prevention Research Institute (DPRI), Kyoto University, Kyoto, 611-0011, Japan \\ E-mail: onishi.masamitsu.7e@kyoto-u.ac.jp
}

\begin{abstract}
Infrastructure projects require a great amount of capital investment resulting from their tremendous size, complexity, and risk. Due to the limitation of public finances, the private sector is invited to participate in infrastructure project development. The private sector can entirely or partially invest in an infrastructure project in the form of a public-private partnership (PPP) scheme, which has been an attractive option for several developing countries, including Vietnam. Unfortunately, despite the PPP scheme will improve project efficiencies and attract capital investments of private investors, the success of PPP implementation is not guaranteed. This paper investigates the critical success factors (CSFs) of PPP infrastructure projects in Vietnam. Relevant data were collected through in-depth interviews with six PPP experts and questionnaire surveys with 150 interviewees and then analyzed by the word cloud technique and the one-way analysis of variance (ANOVA) test. The CSFs were ranked based on the viewpoints of the public sector, the private sector, and the PPP consultants. The outcomes show that there was no significant difference in the perceptions of all three parties concerning the success factors for PPP infrastructure projects in Vietnam. The top five critical success factors are (1) timely land acquisition and appropriate compensation, (2) financial capacity of the private sector, (3) effective project management, (4) favorable and complete legal framework and regulations, and (5) financial feasibility and attraction. Recognizing the CSFs is indispensable to ensure the success of PPP infrastructure project implementation.
\end{abstract}

Keywords - critical success factor (CSF); infrastructure projects; public-private partnership (PPP); Vietnam; word cloud technique.

\section{INTRODUCTION}

Infrastructure performs a crucial role in the economic development of developing countries [1]. Even though the demand for capital investment for infrastructure projects in many nations has been increasing, the public financial investment is limited due to financial constraints. For example, the Vietnamese government must reduce the total investment from $40 \%$ of GDP to $34 \%$ and $30 \%$ of GDP in the years 2012 and 2013, respectively. Consequently, capital investment in infrastructure projects was reduced to $8 \%$ of GDP [2]. For the largest city of Vietnam, Ho Chi Minh city, it needs over 40 billion USD up to the year 2020 to develop infrastructure transportation projects (e.g., six metropolitan projects, expressways, and road projects), but they can only meet $15-20 \%$ of such capital demand [3]. A public-private partnership (PPP) is thus recognized as an option to resolve this problem.

A PPP is considered as a practical approach to deliver value-for-money public infrastructure projects [4]. It is typically a contractual agreement (usually called a concession contract) between the public sector and a private company, where the private sector takes responsibility for all or part of the government's functions binding the business to deliver an essential service for an agreed amount of compensation [5], [6]. It is increasingly used by government and public agencies around the world as a way of increasing services, improving efficiency, and reducing costs [7]. Unfortunately, the success of PPP implementation is not guaranteed [8]. This paper aims to determine the key success factors for PPP infrastructure projects by focusing on those in Vietnam as case studies.

In general, to investigate the project's success, the researchers identify a set of factors that have a substantial 
impact on the project success, which are called critical success factors (CSFs) [9], [10]. A CSF was first mentioned by Rockart [11]. After that, many authors have adopted this concept for project management studies [12], [13]. A CSF is a basis for investors or organizations to obtain the success of a project [14]. CSFs are defined as the main components of activities that are necessary for managers to obtain their targets [15], [16]. CSFs are also defined as the limited number of some components that ensure the successful competitive performance of an organization if they are satisfied [17], [18]. In other words, CSFs are important to identify the main factors that companies should consider to be successful in a project [19].

Project success is associated with the existence of some CSFs [20]. The use of CSFs is the best approach that addresses human and organizational aspects of a project. Many research works have proposed CSFs to illustrate the causes of project success and failure. It is complicated to identify certain significant factors that control the project success because various complex functions are affecting the design, construction, and operation of projects [21].

In recent years, there have been many studies on the CSFs of PPP worldwide. For example, a study on PPP projects in England discussed 14 key factors affecting the success of PPP projects [22]. A study on BOT projects in China analyzed 29 factors in six phases of BOT projects, namely, investment preparation, pre-feasibility study, contracting, operation, and transfer [23]. Thirteen key factors have a considerable impact on the success of BOT projects:

- Clear project identification

- Stable political-economic environment

- Financial support

- Appropriate fee collection

- Affordable risk sharing

- Appropriate contractor selection

- Effective project management

- Technology transfer

- Thorough preparation

- Successful BOT contracts

- Success in construction

- Success in operation

- Success in the transfer phase.

They also analyzed the importance level of each factor according to the viewpoints of the government and the private sector.

In England, 18 factors that had an important impact on the success of PPP projects were investigated and identified [24]. Such factors were divided into five groups, as follows:

- The effective procurement factor group

- The project implementation factor group,

- The government guarantee factor group,

- The favorable economic conditions factor group, and

- The available financial market factor group.

A decision support list, including 13 CSFs of BOT projects in the Middle East, as defined by Kashey [25]. This study also verified and drew experience lessons for airport BOT projects. In Malaysia, 18 CSFs of PPP project implementation were identified by [19]. The results showed that great governance, the commitment to the public and private sectors, a fair legal aspect, a healthy economic policy, and available financial markets are the top five CSFs of PPP projects in Malaysia.

The critical findings of the previous research work from 1992 to 2014 are summarized in Table I. These are the core background for determining the framework of CSFs for PPP infrastructure projects in Vietnam. There have been many studies on CSFs of the PPP projects around the world; few of them are in Vietnam [26], [27]. Moreover, there is no previous study that examined the perception of different stakeholder viewpoints. The unique characteristics of PPP projects in a certain country (herein Vietnam) need to be investigated, especially CSFs. This paper aims to fill such a research gap by examining the CSFs for PPP projects in Vietnam.

\section{MATERIALS AND METHOD}

This study used a questionnaire survey as a primary data collection method. First, we conducted in-depth interviews with six PPP experts in Vietnam: two government officers, two staff members of PPP private firms, and two PPP consultants. Figure 1 illustrates the ranking CSFs for PPP infrastructure projects, which is summarized from our interviews using the word cloud technique. In this technique, the font size indicates the frequency of results [28]. The larger the font size is, the more frequently a word is used [29]. Its purpose is not only to identify important CSFs, but also to present missing CSFs. It can also remove irrelevant CSFs. Finally, 22 CSFs were identified and used in the subsequent large-scale survey, as shown in Table II.

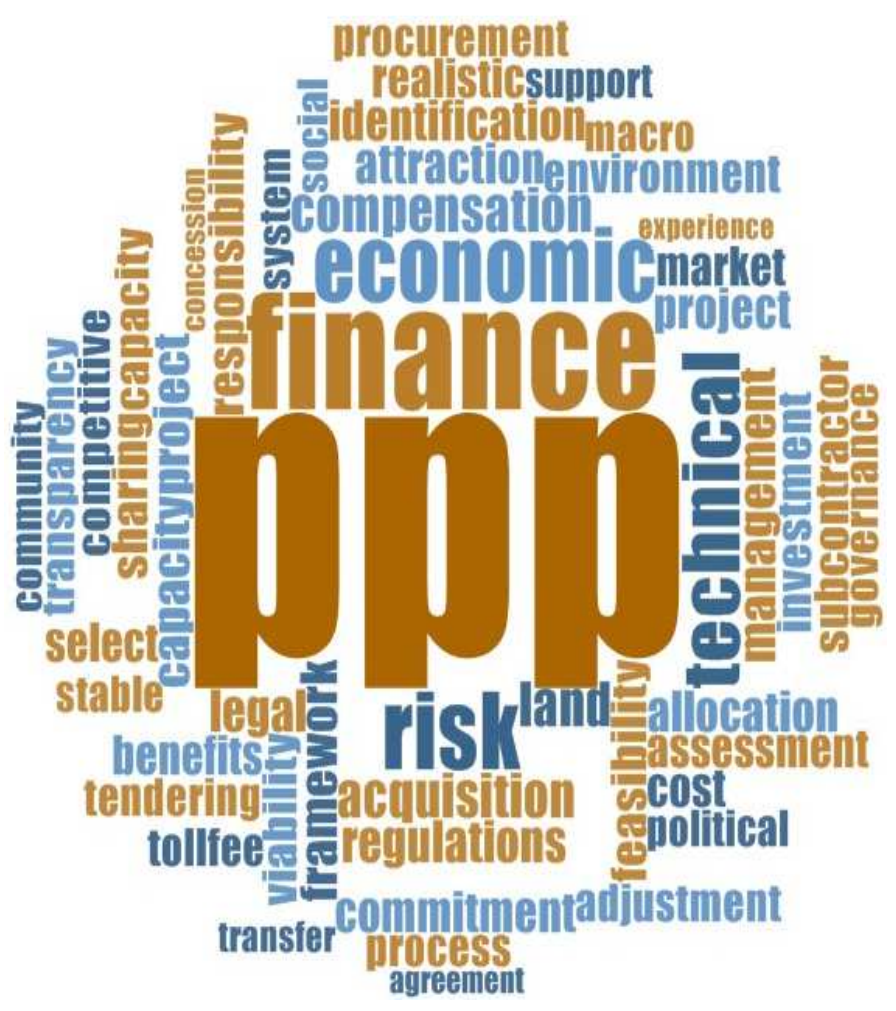

Fig. 1 Word cloud visualization of critical success factors (CSFs) for publicprivate partnership infrastructure projects in Vietnam 
TABLE I

CRITICAL SUCCESS FACTORS (CSFS) OF PPP PROJECTS FROM PAST LITERATURE

\begin{tabular}{|c|c|c|c|c|c|c|c|c|c|c|c|c|c|c|c|c|c|c|c|c|c|c|}
\hline \multirow{2}{*}{ CSFs } & \multicolumn{22}{|c|}{ References* } \\
\hline & [30] & [31] & [32] & \begin{tabular}{|l|l|}
{$[23]$} \\
\end{tabular} & \begin{tabular}{|l|l} 
[33] \\
\end{tabular} & [34] & {$[24]$} & [35] & \begin{tabular}{|l}
{$[36]$} \\
\end{tabular} & [37] & {$[4]$} & {$[38]$} & \begin{tabular}{|l|l}
{$[39]$} \\
\end{tabular} & [40] & {$[41]$} & 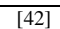 & \begin{tabular}{|l}
{$[43]$} \\
\end{tabular} & [44] & \begin{tabular}{|l}
{$[45]$} \\
\end{tabular} & [19] & 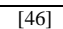 & [47] \\
\hline $\begin{array}{l}\text { Stable macro- } \\
\text { economic } \\
\text { environment }\end{array}$ & & & & $\checkmark$ & $\checkmark$ & & $\checkmark$ & & & & $\checkmark$ & & & & $\checkmark$ & $\checkmark$ & & $\checkmark$ & & $\checkmark$ & & \\
\hline $\begin{array}{l}\text { Stable political } \\
\text { system support }\end{array}$ & & & $\checkmark$ & $\checkmark$ & $\checkmark$ & & & $\checkmark$ & $\checkmark$ & $\checkmark$ & $\checkmark$ & & $\checkmark$ & & $\checkmark$ & & & $\checkmark$ & $\checkmark$ & & & \\
\hline $\begin{array}{l}\text { Favorable and } \\
\text { completed legal } \\
\text { framework }\end{array}$ & & & & & & $\checkmark$ & $\checkmark$ & & & & & & & & $\checkmark$ & $\checkmark$ & & $\checkmark$ & $\checkmark$ & $\checkmark$ & $\checkmark$ & \\
\hline $\begin{array}{l}\text { Transparency } \\
\text { procurement } \\
\text { process }\end{array}$ & & & & & & $\checkmark$ & $\checkmark$ & & $\checkmark$ & & $\checkmark$ & $\checkmark$ & $\checkmark$ & & $\checkmark$ & $\checkmark$ & $\checkmark$ & $\checkmark$ & $\checkmark$ & $\checkmark$ & $\checkmark$ & $\checkmark$ \\
\hline $\begin{array}{l}\text { Good } \\
\text { governance }\end{array}$ & & & & & & & $\checkmark$ & & & & & & $\checkmark$ & & & & & & & $\checkmark$ & $\checkmark$ & $\checkmark$ \\
\hline $\begin{array}{l}\text { Social \& } \\
\text { community } \\
\text { support }\end{array}$ & & & & & & & $\checkmark$ & $\checkmark$ & & $\checkmark$ & $\checkmark$ & & $\checkmark$ & & & & & & & $\checkmark$ & & \\
\hline $\begin{array}{l}\text { Available } \\
\text { financial market }\end{array}$ & & & $\checkmark$ & & & & $\checkmark$ & & $\checkmark$ & & & & & & & & & & $\checkmark$ & & & \\
\hline $\begin{array}{l}\text { Good feasibility } \\
\text { and attraction }\end{array}$ & & & & $\checkmark$ & $\checkmark$ & $\checkmark$ & $\checkmark$ & & & & & & & & & & & $\checkmark$ & & & & $\checkmark$ \\
\hline $\begin{array}{l}\text { Economic } \\
\text { viability and } \\
\text { sound policy }\end{array}$ & & & $\checkmark$ & & & & $\checkmark$ & & & & & & & & $\checkmark$ & $\checkmark$ & & & & & & \\
\hline $\begin{array}{l}\text { Appropriate } \\
\text { project } \\
\text { identification }\end{array}$ & $\checkmark$ & $\checkmark$ & & $\checkmark$ & $\checkmark$ & & & & & & & & & & & & & & $\checkmark$ & & & \\
\hline $\begin{array}{l}\text { Realistic } \\
\text { assessment of } \\
\text { the cost and } \\
\text { benefits }\end{array}$ & & & & & & & $\checkmark$ & & & & & & & & & & & & & $\checkmark$ & & \\
\hline $\begin{array}{l}\text { Flexible toll fee } \\
\text { level and } \\
\text { adjustment }\end{array}$ & & $\checkmark$ & & $\checkmark$ & & & & $\checkmark$ & & & & & & $\checkmark$ & & & & & & & & \\
\hline $\begin{array}{l}\text { Strong financial } \\
\& \text { capacity of } \\
\text { private sector }\end{array}$ & $\checkmark$ & $\checkmark$ & $\checkmark$ & & $\checkmark$ & & $\checkmark$ & $\checkmark$ & & & & & & $\checkmark$ & & $\checkmark$ & $\checkmark$ & & $\checkmark$ & & $\checkmark$ & \\
\hline $\begin{array}{l}\text { Technical } \\
\text { capacity }\end{array}$ & & & & & & & & $\checkmark$ & & & & & $\checkmark$ & & & & & & & & & \\
\hline $\begin{array}{l}\text { Effective project } \\
\text { management }\end{array}$ & & & & $\checkmark$ & & & & $\checkmark$ & & $\checkmark$ & & & & & $\checkmark$ & $\checkmark$ & & $\checkmark$ & $\checkmark$ & & & \\
\hline $\begin{array}{l}\text { Select suitable } \\
\text { subcontractor }\end{array}$ & & & & $\checkmark$ & & & & $\checkmark$ & & & & & & & & & & & & & & \\
\hline $\begin{array}{l}\text { Suitable risk } \\
\text { allocation }\end{array}$ & & $\checkmark$ & & $\checkmark$ & & & $\checkmark$ & $\checkmark$ & $\checkmark$ & $\checkmark$ & & $\checkmark$ & & & $\checkmark$ & $\checkmark$ & & $\checkmark$ & $\checkmark$ & $\checkmark$ & $\checkmark$ & $\checkmark$ \\
\hline $\begin{array}{l}\text { Solid } \\
\text { commitment } \\
\text { and } \\
\text { responsibility } \\
\text { parties }\end{array}$ & & & & & & & $\checkmark$ & & & $\checkmark$ & $\checkmark$ & & $\checkmark$ & & & & $\checkmark$ & & $\checkmark$ & $\checkmark$ & $\checkmark$ & \\
\hline $\begin{array}{l}\text { Technology } \\
\text { innovation \& } \\
\text { transfer }\end{array}$ & $\checkmark$ & $\checkmark$ & & $\checkmark$ & $\checkmark$ & & & & & & & & & & & & & & $\checkmark$ & & & \\
\hline $\begin{array}{l}\text { Experience and } \\
\text { Compatibility } \\
\text { skills parties }\end{array}$ & & & & & $\checkmark$ & & & & & & & & & & & & & & $\checkmark$ & $\checkmark$ & & \\
\hline $\begin{array}{l}\text { Open and } \\
\text { constant } \\
\text { communication }\end{array}$ & & & & & & & & & & $\checkmark$ & & $\checkmark$ & & & & & $\checkmark$ & & & & & \\
\hline $\begin{array}{l}\text { Government } \\
\text { providing } \\
\text { guarantees }\end{array}$ & & & $\checkmark$ & & & & & & & & & & $\checkmark$ & $\checkmark$ & $\checkmark$ & $\checkmark$ & & & & & & \\
\hline Trust & & & & & $\checkmark$ & $\checkmark$ & & & & $\checkmark$ & & & & & & & $\checkmark$ & & & & & \\
\hline $\begin{array}{l}\text { Extensive } \\
\text { demand for the } \\
\text { project }\end{array}$ & & & $\checkmark$ & & & & & & & & & $\checkmark$ & & $\checkmark$ & & & & $\checkmark$ & & & & \\
\hline $\begin{array}{l}\text { Clear design } \\
\text { development }\end{array}$ & & & & & & $\checkmark$ & & & $\checkmark$ & & & & & & & & $\checkmark$ & & & & & \\
\hline $\begin{array}{l}\text { Competitive } \\
\text { financial } \\
\text { proposals }\end{array}$ & & $\checkmark$ & & & & & & & & & & & & & & & & & & & & \\
\hline $\begin{array}{l}\text { Streamline } \\
\text { approval } \\
\text { process }\end{array}$ & & & & & $\checkmark$ & & & & $\checkmark$ & & & & & & & & & & & & & \\
\hline $\begin{array}{l}\text { Good leadership } \\
\& \\
\text { entrepreneurship } \\
\text { skills }\end{array}$ & $\checkmark$ & $\checkmark$ & & & & & & & & & & & & & & & & & & & & \\
\hline $\begin{array}{l}\text { Well organized } \\
\text { public agency }\end{array}$ & & & & & & & $\checkmark$ & & & & & & & & & & & & & & $\checkmark$ & \\
\hline $\begin{array}{l}\text { Obvious } \\
\text { objectives }\end{array}$ & & & & & & & & & & & & & & $\checkmark$ & & & $\checkmark$ & & & & & \\
\hline $\begin{array}{l}\text { Employment of } \\
\text { professional } \\
\text { advisors }\end{array}$ & & & & & & & & & & $\checkmark$ & & $\checkmark$ & & & & & & & & & & $\checkmark$ \\
\hline $\begin{array}{l}\text { Monetary } \\
\text { accountability }\end{array}$ & & & & & & $\checkmark$ & & & & & & & & & & & & & & & & \\
\hline $\begin{array}{l}\text { Consistent } \\
\text { controlling }\end{array}$ & & & & & & & & & & & & $\checkmark$ & & & & & & & & & & \\
\hline $\begin{array}{l}\text { Reliable service } \\
\text { delivery }\end{array}$ & & & & & & & & & & & & $\checkmark$ & & $\checkmark$ & & & & & & & & \\
\hline $\begin{array}{l}\text { Environmental } \\
\text { impact }\end{array}$ & & $\checkmark$ & & & $\checkmark$ & & & & & & & & & & & $\checkmark$ & & & & & & $\checkmark$ \\
\hline
\end{tabular}


A total of 150 questionnaires were distributed to the qualified respondents, but only 112 questionnaires were returned and considered valid (i.e., $74.67 \%$ response rate), as shown in Table III. The data were analyzed by IBM SPSS software to determine the importance of each of the 22 CSFs based on the mean score of the 5-point Likert scale. The CSFs were then ranked according to their scores assessed by the public sector, the private sector, and the consultants. Finally, the one-way ANOVA technique was applied to evaluate the difference in the perceptions of these three parties.

TABLE II

LIST OF 22 PPP CRITICAL SUCCESS FACTORS (CSFS)

\begin{tabular}{|c|l|}
\hline No & \multicolumn{1}{|c|}{ CSFs of PPP projects } \\
\hline 1 & Stable macroeconomic \\
\hline 2 & Stable political system \\
\hline 3 & $\begin{array}{l}\text { Favorable and completed legal framework and } \\
\text { regulations }\end{array}$ \\
\hline 4 & Favorable investment environment \\
\hline 5 & $\begin{array}{l}\text { Transparency procurement and competitive tendering } \\
\text { process }\end{array}$ \\
\hline 6 & Good governance \\
\hline 7 & Social and community support \\
\hline 8 & Timely land acquisition and appropriate compensation \\
\hline 9 & Available financial market \\
\hline 10 & Financial feasibility and attraction \\
\hline 11 & Economic viability \\
\hline 12 & Appropriate project identification \\
\hline 13 & A realistic assessment of the cost and benefits \\
\hline 14 & Flexible toll fee adjustment \\
\hline 15 & Financial capacity \\
\hline 16 & Technology transfer \\
\hline 17 & Effective project management \\
\hline 18 & Select suitable subcontractor \\
\hline 19 & Appropriate risk allocation and risk-sharing \\
\hline 20 & $\begin{array}{l}\text { Solid commitment and responsibility of public and } \\
\text { private sectors }\end{array}$ \\
\hline 21 & Technical capacity \\
\hline 22 & $\begin{array}{l}\text { Concrete, precise and flexible in the concession } \\
\text { agreement }\end{array}$ \\
\hline & \\
\hline 12
\end{tabular}

TABLE III

DISTRIBUTION OF THE RESPONDENTS ACCORDING TO THEIR ORGANIZATIONS AND EXPERIENCE

\begin{tabular}{|l|c|c|c|c|}
\hline \multirow{2}{*}{ Experience } & \multicolumn{3}{c|}{ Correspondents } & \multirow{2}{*}{ Total } \\
\cline { 2 - 4 } & Public & Private & Consultant & \\
\hline Fewer than 5 years & 14 & 21 & 7 & 42 \\
\hline 6-10 years & 6 & 10 & 7 & 23 \\
\hline 11-15 years & 5 & 13 & 9 & 27 \\
\hline 15 years and more & 6 & 8 & 6 & 20 \\
\hline Total & 31 & 52 & 29 & 112 \\
\hline
\end{tabular}

\section{RESULTS AND DISCUSSION}

As can be seen, there were 31 respondents from the public sector $(27.68 \%)$, which was the fewest among the three parties. This is because there were a limited number of state agencies involved in the PPP projects of Vietnam [48]. As a result, the government officers who were qualified to participate in our data survey were also limited. These respondents included the personnel from the Department of Planning and Investment, Department of Transport, Department of Construction, Department of Finance of the People's Committees of Hochiminh City, and other cities. Meanwhile, there were 52 respondents from the private sector $(46.43 \%)$, which encompassed the organizations or companies that were or have been involved in PPP projects. They were contractors and subcontractors that were consortium or joint venture members of the PPP projects. Finally, 29 participants were PPP consultants (25.89\%). They were construction consulting companies, law firms, as well as scholars and researchers in institutes and universities.

Among these 112 experienced practitioners, there were 42 respondents $(37.5 \%)$ possessed fewer than five years of work experience in PPP. Approximately $20.54 \%$ of the interviewees ( 23 persons) had 6 to 10 years of experience in PPP projects. The remaining groups were the respondents having 11 to 15 years of experience (27 persons, $24.11 \%$ ) and those having 15 years of experience or more above (20 persons, $17.86 \%$ ).

Table IV displayed the mean scores and the ranks of the 22 CSFs of PPP infrastructure projects in Vietnam, according to the three groups of respondents. Two factors, namely technology transfer, and concrete, precise, and flexible concession agreement, were not presented due to their low mean score (less than 3.0). According to all three groups of the respondents, the top five CSFs were: (1) timely land acquisition and appropriate compensation, (2) financial capacity of the private sector, (3) effective project management, (4) favorable and complete legal framework and regulations, and (5) financial feasibility and attraction.

The first factor, timely land acquisition, and appropriate compensation, had barely been mentioned in the previous studies but was considered the most important success factor of PPP projects in Vietnam. This result corresponded with the fact that $60 \%$ of PPP projects in Vietnam failed or delayed resulting from unsatisfying compensatory mechanisms and compensations (i.e., compensation rates lower than market prices), lack planning, corruption, and lack of compensation funds. These caused prolonged construction time, inflated costs, and poor quality of construction work. For example, the Deo Ca mountain pass tunnel project, which was a BOT project located on National Highway $1 \mathrm{~A}$ in Vietnam, significantly delayed because the construction site of the southern road construction work package could not be handed over to the contractor as planned. The experts also confirmed the criticality of this factor from the in-depth interviews. Thus, this CSF was a unique characteristic of PPP projects in Vietnam.

The financial capacity of the private sector was ranked as the second most important CSF. This result agrees with those of [23], [49], [24]. They claimed that the poor financial capacity of the private sector adversely affects the schedule of PPP projects and the quality of construction works. Many 
private investors of the PPP infrastructure projects in Vietnam had a sound technical capacity, but they had to mobilize capital from many different financial institutions. Thus, the identification of their financial capability helps further analyze issues and ensures the success of the PPP projects.

Effective project management was rated as the third most essential factor for PPP infrastructure projects in Vietnam. While private investors were delivering projects in the form of BOT, they must organize their project management unit. It was extremely risky if an investor was a construction company with limited project management experience [50]. According to the Bureau of the Ministry of Transport in
Vietnam, project management units (PMUs) with unprofessional project management capacity and skill must be encountered with various difficulties during project implementation, especially when organizing and coordinating large scale, complex, and urgent projects. In a project where the consultant proposes unreasonable design solutions causing enormous waste, the PMU m not be able to respond appropriately. In some past projects, incapable PMUs could not perform according to the committed project schedule. Some PMUs even could not prepare a monthly progress report as required by the contract. For example, the Hochiminh highway project has due to the change of project organization and managerial personnel.

TABLE IV

RANKING OF THE CSFS FOR PPP INFRASTRUCTURE PROJECTS IN VIETNAM

\begin{tabular}{|c|c|c|c|c|c|c|c|c|c|c|}
\hline \multirow{2}{*}{ No } & \multirow{2}{*}{ CSFs } & \multicolumn{2}{|c|}{ Overall } & \multicolumn{2}{|c|}{ Public Sector } & \multicolumn{2}{|c|}{ Private Sector } & \multicolumn{2}{|c|}{ Consultant } & \multirow{2}{*}{ Sig. } \\
\hline & & Mean & Rank & Mean & Rank & Mean & Rank & Mean & Rank & \\
\hline 1 & $\begin{array}{l}\text { Timely land acquisition and } \\
\text { appropriate compensation }\end{array}$ & 4.41 & 1 & 4.48 & 1 & 4.48 & 1 & 4.21 & 2 & 0.341 \\
\hline 2 & Financial capacity of the private sector & 4.21 & 2 & 4.23 & 3 & 4.27 & 2 & 4.08 & 4 & 0.616 \\
\hline 3 & Effective project management & 4.06 & 3 & 4.16 & 4 & 4.01 & 5 & 4.04 & 6 & 0.739 \\
\hline 4 & $\begin{array}{l}\text { Favorable and complete legal } \\
\text { framework and regulations }\end{array}$ & 4.05 & 4 & 4.00 & 6 & 4.02 & 4 & 4.17 & 3 & 0.694 \\
\hline 5 & Financial feasibility and attraction & 4.00 & 5 & 3.74 & 10 & 4.00 & 6 & 4.28 & 1 & 0.075 \\
\hline 6 & Appropriate project identification & 3.96 & 6 & 4.26 & 2 & 3.85 & 10 & 3.86 & 14 & 0.138 \\
\hline 7 & $\begin{array}{l}\text { Strong commitment, responsibility of } \\
\text { the public and private sectors }\end{array}$ & 3.94 & 7 & 4.03 & 5 & 3.83 & 11 & 4.03 & 7 & 0.479 \\
\hline 8 & $\begin{array}{l}\text { Appropriate risk allocation and risk } \\
\text { sharing }\end{array}$ & 3.93 & 8 & 3.94 & 7 & 4.04 & 3 & 3.72 & 16 & 0.353 \\
\hline 9 & Economic viability & 3.89 & 9 & 3.77 & 9 & 3.87 & 9 & 4.07 & 5 & 0.518 \\
\hline 10 & Favorable investment environment & 3.88 & 10 & 3.72 & 11 & 3.92 & 8 & 3.97 & 9 & 0.496 \\
\hline 11 & Available financial market & 3.79 & 11 & 3.61 & 13 & 3.81 & 12 & 3.90 & 13 & 0.528 \\
\hline 12 & $\begin{array}{l}\text { Realistic assessment of the cost and } \\
\text { benefits }\end{array}$ & 3.78 & 12 & 3.81 & 8 & 3.67 & 15 & 3.93 & 11 & 0.449 \\
\hline 13 & Select suitable subcontractor & 3.76 & 13 & 3.52 & 16 & 3.75 & 14 & 4.02 & 8 & 0.151 \\
\hline 14 & $\begin{array}{l}\text { Transparent procurement and } \\
\text { competitive tendering process }\end{array}$ & 3.74 & 14 & 3.42 & 18 & 3.96 & 7 & 3.69 & 17 & 0.069 \\
\hline 15 & Good governance & 3.72 & 15 & 3.45 & 17 & 3.77 & 13 & 3.92 & 12 & 0.138 \\
\hline 16 & Technical capacity & 3.69 & 16 & 3.60 & 14 & 3.58 & 16 & 3.96 & 10 & 0.179 \\
\hline 17 & Stable macro-economic & 3.58 & 17 & 3.71 & 12 & 3.52 & 17 & 3.55 & 19 & 0.609 \\
\hline 18 & Stable political system & 3.53 & 18 & 3.58 & 15 & 3.40 & 18 & 3.68 & 18 & 0.440 \\
\hline 19 & Social and community support & 3.37 & 19 & 3.13 & 20 & 3.31 & 20 & 3.76 & 15 & 0.058 \\
\hline 20 & Flexible toll fee adjustment & 3.33 & 20 & 3.19 & 19 & 3.35 & 19 & 3.45 & 20 & 0.582 \\
\hline 21 & $\begin{array}{l}\text { Concrete, precise, and flexible } \\
\text { concession agreement }\end{array}$ & 2.43 & 21 & 2.55 & 21 & 2.44 & 21 & 2.28 & 22 & - \\
\hline 22 & Technology transfer & 2.39 & 22 & 2.45 & 22 & 2.40 & 22 & 2.31 & 21 & \\
\hline
\end{tabular}

Another CSF for PPP infrastructure projects in Vietnam perceived by the respondents was favorable and complete legal framework and regulations. This factor had been mentioned in many previous studies [19]. The legal framework must be understood in a broad sense, including legal and sub-law documents, as well as regulatory documents, which may affect project implementations. If a good PPP legal framework exists, PPP projects tend to encounter fewer problems. Furthermore, a clear legal framework is essential for PPP projects to prevent corruption. Unfortunately, in the present, the Vietnamese government has not issued a law specifically on PPP, except for some decrees and guiding circulars for this investment scheme. Their provisions are also not specific and unclear.
Financial feasibility and attraction were ranked as the fifth most critical factor. The PPP project must be financially feasible to ensure capital recovery for investors. The financial package is another consideration by investors to participate in PPP projects. The state must pay attention to this factor because it greatly affects the public budget and the repayment plans of investors. For example, the PPP Dau Giay - Phan Thiet expressway project attracted many investors. When the bid was closed, there were seven wellknown bidders and consortiums of international investors; they are as follows:

- Egis Projet SA \& Consortium of IJM Corp Bernard

- Hyundai E\&C-Korea Expressway Corp (Korea)

- Oriental Structures Engineering PVT (India)

- Vinci Concessions (France) 
- IL\&FS Transportation Network

- First Pacific \& Metro Pacific Investment (Hong Kong and the Philippines).

The estimated cost of this project was 757 million. The owner's equity was $20 \%$, whereas $80 \%$ was long-term loans from the World Bank at a lending rate based on LIBOR from the International Bank for Reconstruction and Development (IBRD). This was a PPP project that was successful in attracting prominent investors due to this CSF.

Among the $22 \mathrm{CSFs}$, technology transfer was ranked last by respondents with a mean score of 2.39. This result does not mean that it is not a major factor for successful PPP infrastructure projects in Vietnam. Because most of PPP projects in Vietnam are conventional transportation systems such as bridges, roads, and highways, the technology of which is not advanced. Technology transfer is, therefore, less concerned than the other factors.

To investigate the differences in the perceptions of the public sector, the private sector, and consultants regarding the importance of the 22 CSFs, a one-way ANOVA technique was conducted. The results in Table IV show that all 22 CSFs have significance values greater than 0.05 , which means that there was no significant difference in the perceptions of the three parties on the CSFs of PPP infrastructure projects in Vietnam.

- As can be seen, the top five CSFs perceived by the public sector were as follows:

- Timely land acquisition and appropriate compensation

- Appropriate project identification

- Financial capacity of the private sector

- Effective project management

- Strong commitment, and responsibility of the public and private sectors.

Meanwhile, for the private sector, the top five CSFs were (1) timely land acquisition and appropriate compensation, (2) financial capacity, (3) appropriate risk allocation and risk sharing, (4) favorable and complete legal framework and regulations, and (5) effective project management. From the consultants' perspectives, the CSFs were (1) financial feasibility and attraction, (2) timely land acquisition and appropriate compensation, (3) favorable and completed legal framework and regulations, (4) financial capacity of the private sector, and (5) economic viability. Based on these results, the rankings of CSFs of PPP projects by the public sector, the private sector, and consultants were quite consistent. Both timely land acquisition and appropriate compensation and financial capacity of the private sector were ranked in the top five for all three groups. This corresponds to the fact that most PPP projects in Vietnam were delayed due to slow land clearance and compensation. For example, the compensation price from the government for land was lower than its actual market price. Moreover, it was even more complicated when the compensation rates are different from one to another city [51]. Thus, the main concern when implementing a PPP project in Vietnam is the real capacity of investors. The criticality of an investor's financial capability was also emphasized in past studies [52], [53]. In Vietnam, investors are mainly state-owned construction corporations. However, these companies operate primarily on the basis of loans with very low profits, or even losses, so the financial capacity to implement PPP projects is very weak.

Both effective project management and favorable and complete legal framework and regulations were also important factors among all three groups of respondents. Effective project management is extremely crucial, especially during the construction phase of PPP projects. The legal institutions in Vietnam have not created favorable conditions for PPP projects. As a result, the current legal system on PPP is adequate, unclear, and inconsistent. PPP contracts are merely normal business contracts with unclear risk sharing.

Appropriate risk allocation and risk-sharing was rated third by the private sector but was ranked seventh and sixteenth by the public sector and the consultants, respectively. The difference in the ranking among the three sectors might result from the fact that under the PPP scheme, there are more risks and uncertainties borne by the private sector [54]. Hence, the private sector is more concerned about this factor than the public sector, and the consultants are. Changing the scope of a PPP project is a dominant risk in Vietnam, resulting from frequent changes in the nation's infrastructure development planning strategy. The scopes of many large PPP projects were reviewed and adjusted in 2013 by the Ministry of Transport. For example, the PPP Ben Luc - Long Thanh expressway project was changed its length of the cable stay span of the bridge from $460 \mathrm{~m}$ to $375 \mathrm{~m}$.

\section{CONCLUSION}

The public-private partnership (PPP) form has been declared as bringing a new life to the infrastructure development in Vietnam. It is known as an essential alternative approach for PPP developing infrastructure of a country due to its role in pushing up economic values or fostering the sustainability of the sector. Yet, the success of PPP project implementation is not guaranteed. This paper investigates $22 \mathrm{CSF}$ of the PPP infrastructure projects in Vietnam. The top five factors are as follows: Timely land acquisition and appropriate compensation; Strong financial and capacity of the private sector; Effective project management; Favorable and completed legal framework; Financial feasibility.

Even though the rankings of some CSFs were different among the public sector, the private sector, and the consultants, there was no significant difference in their perceptions. These results can benefit the government, concessionaires, and all PPP stakeholders for realizing important issues to ensure the success of PPP projects.

\section{ACKNOWLEDGMENT}

The authors gratefully acknowledge the AUN/SEED-Net (JICA), Chulalongkorn University (Thailand), Kyoto University (Japan), and Ho Chi Minh City Open University (Vietnam) for their financial supports for this research.

\section{REFERENCES}

[1] A. P. C. Chan, D. W. M. Chan, Y. H. Chiang, B. S. Tang, E. H. W. Chan, and K. S. K. Ho, "Exploring critical success factors for partnering in construction projects," Journal of Construction Engineering and Management, vol. 130, pp. 188-198, Apr. 2004. 
[2] S. T. Do, V. Likhitruangsilp, M. Onishi, and P. T. Nguyen, "Different perceptions of concern factors for the strategic investment of the private sector in public-privatete partnership transportation projects," ASEAN Engineering Journal, vol. 05, pp. 05-25, Dec. 2016.

[3] D. Giang, and L. Pheng, "Critical factors affecting the efficient use of public investments in infrastructure in Vietnam," Journal of Infrastructure Systems, pp. 0071-00710, Sep. 2015.

[4] A. P. Chan, P. T. Lam, D. W. Chan, E. Cheung, and Y. Ke, "Critical success factors for PPPs in infrastructure developments: Chinese perspective," Journal of Construction Engineering and Management, vol. 136, pp. 484-494 May. 2010.

[5] S. M. Levy, Build, operate, transfer: Paving the way for tomorrow's infrastructure, John Wiley \& Sons, New York, 1996.

[6] K. Rintala, D. Root, G. Ive, and P. Bowen, "Organizing a bidding competition for a toll road concession in South Africa: the case of Chapman's peak drive," Journal of Management in Engineering, vol. 24, pp. 146-155, Jul. 2008.

[7] C. Fernandes, M. Ferreira, and F. Moura, "PPPs-True financial costs and hidden returns," Transport Reviews, vol. 36, pp. 207-227, Sep. 2016.

[8] A. P.C. Chan, and E. Cheung, Public Private Partnerships in International Construction: Learning From Case Studies, Routledge, 2014.

[9] A. A. Hamid, and Z. Mansor, "Client's readiness assessment success factors for outsourcing software projects," International Journal on Advanced Science, Engineering and Information Technology, vol. 6, pp. 820-827, Nov. 2016

[10] M. Zammani, and R. Razali, "An empirical study of information security management success factors," International Journal on Advanced Science, Engineering and Information Technology, vol. 6, pp. 904-913, Nov. 2016.

[11] J. F. Rockart, "Current uses of the critical success factors process," in Proc. of the Fourteenth Annual Conference of the Society for Information Management, 1982.

[12] L. C. M. Tang, B. Atkinson, and R. R. Zou, "An entropy-based SWOT evaluation process of critical success factors for international market entry: a case study of a medium-sized consulting company," Construction Management and Economics, vol. 30, pp. 821-834, Jul. 2012.

[13] W. Zou, M. Kumaraswamy, J. Chung, and J. Wong, "Identifying the critical success factors for relationship management in PPP projects," International Journal of Project Management, vol. 32, pp. 265-274, Feb. 2014.

[14] B. Esmaeili, E. Pellicer, and K. R. Molenaar, "Critical Success Factors for Construction Projects," in Project Management and Engineering Research, Proc. of the 18th International AEIPRO Congress, 2016.

[15] P. V. Nguyen, P. T. Nguyen, D. B. V. Huynh, and L. H. T. T. Q. Nguyen, "Critical factors affecting the happiness: A Vietnamese perspective," International Journal of Economic Research, vol. 14, pp. 145-152, Jan. 2017.

[16] Iram, N., B. Khan, M. S. Ahmad, and U. F. Sahibzada," Critical factors influencing the project success: an analysis of projects in manufacturing and construction industries in Punjab, Pakistan," International Journal of Business Studies Review, vol. 01, pp. 41-52, Mar. 2017.

[17] J. Won, G. Lee, C. Dossick, and J. Messner, "Where to focus for successful adoption of Building Information Modeling within organization," Journal of Construction Engineering and Management, vol. 139, pp. 0141-01410, Nov. 2013.

[18] G. Aerts, T. Grage, M. Dooms, and E. Haezendonck, "Public-private partnerships for the provision of port infrastructure: an explorative multi-actor perspective on critical success factors," The Asian Journal of Shipping and Logistics, vol. 30, pp. 273-298, Dec. 2014.

[19] S. Ismail, "Critical success factors of public private partnership (PPP) implementation in Malaysia", Asia-Pacific Journal of Business Administration, vol. 5, pp. 06-19, Jan. 2013.

[20] J. K. Pinto, and J. G. Covin, "Critical factors in project implementation: a comparison of construction and R\&D projects," Technovation, vol. 9, pp. 49-62, May, 1989.

[21] M. Parfitt, and V. Sanvido, "Checklist of critical success factors for building projects," Journal of Management in Engineering, vol. 9, pp. 243-249, Jul. 1993.

[22] R. Morledge, and K. Owen, "Critical success factors in PFI projects," in Annual ARCOM Conference, 1998.
[23] L. Qiao, S. Q. Wang, R. L. Tiong, and T. S. Chan, "Framework for critical success factors of BOT projects in China," The Journal of Structured Finance, vol. 7, pp. 53-61, Aug. 2001.

[24] B. Li, A. Akintoye, P. J. Edwards, and C. Hardcastle, "Critical success factors for PPP/PFI projects in the UK construction industry," Construction management and economics, vol. 23, pp. 459-471, Jun. 2005.

[25] M. Kashey, "Critical success factors for Build Operate Transfer (BOT) projects: lessons learned from airport projects," M. Sci. Thesis, Middle East Technical University, Aug. 2011.

[26] T. E. Kwofie, S. Afram, E. Botchway, "A critical success model for PPP public housing delivery in Ghana," Built Environment Project and Asset Management, vol. 6, pp. 58-73, Jan. 2016.

[27] S. O. Babatunde, S. Perera, L. Zhou, and C. Udeaja, "Stakeholder perceptions on critical success factors for public-private partnership projects in Nigeria," Built Environment Project and Asset Management, vol. 6, pp. 74-91, Jan. 2016.

[28] P. T. Nguyen, and V. Likhitruangsilp, "Identification risk factors affecting concession period length for public-private partnership infrastructure projects," International Journal of Civil Engineering and Technology, vol. 8, pp.342-348, Jun. 2017.

[29] S. A. Barrett, J. P. Spillane, and J. B. Lim, "Early implementation of building information modeling into a cold-formed steel company: providing novel project management techniques and solutions to industry," American Journal of Civil Engineering and Architecture, vol. 1, pp. 164-173, Nov. 2013.

[30] R. L. K. Tiong, K. Yeo, and S. McCarthy, "Critical success factors in winning BOT contracts," Journal of Construction Engineering and Management, vol. 118, pp. 217-228, Jun. 1992.

[31] R. L. K. Tiong, "CSFs in competitive tendering and negotiation model for BOT projects," Journal of Construction Engineering and Management, vol. 122, pp. 205-211, Sep. 1996.

[32] I. D. Ozdoganm, and M. T. Birgonul, "A decision support framework for project sponsors in the planning stage of build-operate-transfer (BOT) projects," Construction Management and Economics, vol. 18, pp. 343-353, Oct. 2000.

[33] M. Jefferies, R. Gameson, and S. Rowlinson, "Critical success factors of the BOOT procurement system: reflections from the Stadium Australia case study," Engineering Construction and Architectural Management, vol. 9, pp. 352-361, Jul. 2002.

[34] J. Dima, "Success and failure mechanisms of public private partnerships (PPPs) in developing countries: Insights from the Lebanese context," International Journal of Public Sector Management, vol. 17, pp. 414-430, Oct. 2004.

[35] X. Zhang, "Critical success factors for public-private partnerships in infrastructure development," Journal of Construction Engineering and Management, vol. 131, pp. 03-14, Jan. 2005.

[36] J. Marcus, "Critical success factors of public private sector partnerships: A case study of the Sydney SuperDome," Engineering, Construction and Architectural Management, vol. 13, pp. 451-462, Oct. 2006.

[37] J. Carol, and C. Sang-Ok, "Success factors: public works and publicprivate partnerships," International Journal of Public Sector Management, vol. 21, pp. 637-657, Dec. 2008.

[38] X. Meng, Q. Zhao, and Q. Shen, "Critical success factors for Transfer-Operate-Transfer urban water supply projects in China," Journal of Management in Engineering, vol. 27, pp. 243-251, Oct. 2011.

[39] M. J. Gannon, and N. J. Smith, "An effective outline business case to facilitate successful decision-making," Construction Management and Economics, vol. 29, pp. 185-197, Feb. 2011.

[40] S.T. Ng, Y. M. W. Wong, and J. M. W. Wong, "Factors influencing the success of PPP at feasibility stage - A tripartite comparison study in Hong Kong," Habitat International, vol. 36, pp. 423-432, Oct. 2012.

[41] S. O. Babatunde, A. Opawole, and O. E. Akinsiku, "Critical success factors in public-private partnership (PPP) on infrastructure delivery in Nigeria," Journal of Facilities Management, vol. 10, pp. 212-225, Jun. 2012.

[42] C. Esther, P. C. C. Albert, and K. Stephen, "Factors contributing to successful public private partnership projects: Comparing Hong Kong with Australia and the United Kingdom," Journal of Facilities Management, vol. 10, pp. 45-58, Feb. 2012.

[43] L. Tang, Q. Shen, M. Skitmore, and E. W. L. Cheng, "Ranked critical factors in PPP briefings," Journal of Management in Engineering, vol. 29, pp. 164-171, Apr. 2012. 
[44] G. Mladenovic, N. Vajdic, B. Wündsch, and A. Temeljotov-Salaj, "Use of key performance indicators for PPP transport projects to meet stakeholders' performance objectives," Built Environment Project and Asset Management, vol. 3, pp. 228-249, Apr. 2013.

[45] A. B. Yusof, and B. Salami, "Success factors for Build Operate Transfer (BOT) power plant projects in Iran," International Journal of Modern Engineering Research, vol. 3, pp. 334-320, Jan. 2013.

[46] B. G. Hwang, X. Zhao, and M. J. S. Gay, "Public private partnership projects in Singapore: Factors, critical risks and preferred risk allocation from the perspective of contractors," International Journal of Project Management, vol. 31, pp. 424-433, Apr. 2013.

[47] J. Liu, P. E. D. Love, J. Smith, M. Regan, and P. Davis, "Life cycle critical success factors for public-private partnership infrastructure projects," Journal of Management in Engineering, vol. 31, pp. 07310737, Sep. 2014.

[48] G. Dang, and L. S. Pheng, Infrastructure investments in developing economies. Springer, 2015.

[49] S. T. Do, V. Likhitruangsilp, M. Onishi, and P. T. Nguyen, "Impacts of risk factors on the performance of Public-Private Partnership transportation projects in Vietnam," ASEAN Engineering Journal, vol. 6, p.01-24, Jan. 2017.
[50] A. Hidayatno, A. O. Moeis, A. Sutrisno, and W. Maulidiah, "Risk impact analysis on the investment of drinking water supply system development using project risk management," International Journal of Technology, vol. 6, pp. 894-904, Oct. 2015.

[51] N. D. Long, S. Ogunlana, T. Quang, and K. C. Lam, "Large construction projects in developing countries: a case study from Vietnam," International Journal of Project Management, vol. 22, pp. 553-561, Oct. 2004.

[52] S. Yun, W. Jung, S. H. Han, and H. Park, "Critical organizational success factors for public private partnership projects - a comparison of solicited and unsolicited proposals," Journal of Civil Engineering and Management, vol. 21, pp. 131-143, Jan. 2015.

[53] R. Osei-Kyei, and A.P.C. Chan, "Review of studies on the Critical Success Factors for Public-Private Partnership (PPP) projects from 1990 to 2013," International Journal of Project Management, vol. 33, pp. 1335-1346, Aug. 2015.

[54] K. Iyer, and M. Sagheer, "Hierarchical structuring of PPP risks using interpretative structural modeling," Journal of Construction Engineering and Management, vol. 136, pp. 151-159, Feb. 2010. 